Food, Dairy and Home Economic Research

http:/www.journals.zu.edu.eg/journalDisplay.aspx?Journalld=1\&queryType=Master

\title{
TECHNOLOGICAL STUDIES ON PERFORMANCE OF SOME SUGAR CANE VARIETIES
}

\author{
Reda A. Gomaa ${ }^{1}$ and A.B.A. El-Taib ${ }^{2}$ \\ 1. Food Sci. and Technol. Dept., Fac. Agric. and Natural Res., Aswan Univ., Egypt \\ 2. Agron. Dept., Fac. Agric. and Natural Res., Aswan Univ., Egypt
}

Received: 18/02/2019 ; Accepted: 18/03/2019

\begin{abstract}
The present study was carried out to study performance and milling quality of the plant (PC), first (FR), second (SR) and third ratoon (TR) crops of two varieties of sugar cane i.e., Giza 99/103 and Giza 99/160 during period from January to March of 2016/2017 working season. Both varieties were planted under comparable conditions at Kom Ombo Sugar Cane Research Station Farm, Aswan Governorate, Egypt. Results revealed that both varieties gave the highest normal juice extraction average of $79.2 \%$ by the onset of January, bagasse (\%) cane showed an opposite trend to normal juice extraction whereas G 99/103 and G 99/160 recorded 36.8 and 37.3\%, respectively. The highest pol extraction reported for G $99 / 160$ was 93.2 and lower pol (\%) bagasse (2.64) compared to 3.15 for Giza 99/103. Sucrose reduction factor of the standard variety G 99/103 showed insignificant variations among the different crops with an average of 0.98 for all the crops and 0.97 with $G 99 / 160$ variety. G 99/160 variety had an average varietal correction factor of 0.986 . The recorded general average for all crops and test dates for pol (\%) cane, estimated recoverable sugars, pol (\%) normal juice and normal juice purity for the variety Giza 99/103 were 16.00, 14.75, 18.82 and 88.65; respectively, compared to $14.63,13.41,17.50$ and 88.2 for Giza 99/160 variety.
\end{abstract}

Key words: Sugar cane, milling quality, normal juice extraction, bagasse, sucrose reduction factor, juice purity, estimated recoverable sugar.

\section{INTRODUCTION}

The cane sugar industry has been started in Egypt since 1868 with six sugar factories. In 1881 the General Company for Sugar and Refining was established. From 1868 till 1956 a number of organization changes have been done. Year 1956 was amalgamation of the two companies the Egyptian Distillery and the sugar Refining Company under the Society Des Sucrenes ET Distillene D' Egypt abbreviated as SSDE due to the growing expansion of the diversification activity the company's name was changed to Sugar and Integrated Industries Company (SIIC). Today, Egyptian Sugar and Integrated Industries Company (ESIIC). ESIIC possess eight sugar factories which are lying in Upper Egypt Governorates. The annual crushing capacity of these sugar factories was more than 10 million tons of cane (Shweil, 1999). Production of good quality white sugar the aim of the economical sugar manufacturing from sugar cane is preservation, extraction and recovery of the maximum yield of sucrose from sugar cane. The steps of raw sugar cane processing are: juice extraction, clarification, evaporation, crystallization, centrifugation, and final drying of the sugar production (Anon, 1974; Cargill and Winterbach, 1996; Prieto, 1997). The Sugar care processing comprised extraction of the juice from the sugar cane sticks using a roller mill apparatus or diffuser apparatus, filtration of the extracted sugar cane juice through a screen filters, stabilization of the $\mathrm{pH}$ of the juice in a non-acidic solution of calcium hydroxide, flocculation of the sugar

\footnotetext{
* Corresponding author: Tel. : +201004989619

E-mail address: reda.gomaa82@yahoo.com
} 
cane juice with the mixture of water and natural flocculate product, evaporation of the sugar cane juice concentrate and extraction of the sugar cane from evaporator (Gonzaies, 2001).

The purpose of clarification process is to remove impurities from the juice as early as possible in process. This elimination has to be done to prevent the loss sucrose or reducing sugars in a considerable quantity. The juice usually contains considerable colloidal and fine suspended matters, which are removed by clarification and addition of some soluble compounds, are also done by means of chemical treatment, heating and settling. The concentrated clarified juice resulting from the fourth vessel is called syrup (Laksameethanasana et al., 2012). The rate of syrup withdrawal is controlled to give the desired brix value. The operation known in the factory as sugar boiling is essentially the process of crystallization, which is carried in single effect vacuum evaporators designed for handing viscous materials and known as vacuum pans. The vacuum pan is thus an evaporative crystallizer, i.e. a crystallizer in which degree of supersaturation is controlled and maintained by evaporating solvent as a solute crystallizes out.

At Kom Ombo sugar factory, the extraction of the juice from cane was done by the milling tandem and diffusion system. In diffusion system the bagasse coming out from the first mill is fed to the diffuser; which is followed by two dewatering mills then the bagasse is subjected to counter current washing with lower concentration juice.

The present study was carried out to study performance and milling quality of the plant (PC), first (FR), second (SR) and third ratoon (TR) crops of two varieties of sugar cane i.e., Giza 99/103 and Giza 99/160 during period from January to March of 2016/2017 working season.

\section{MATERIALS AND METHODS}

\section{Materials}

\section{Cane sampling for testing varietal performance}

The plant (PC), first (FR), second (SR) and third ratoon (TR) crops of the commercially planted cane varieties, Giza 99/103 and Giza $99 / 160$ were used in this study. Both varieties were planted under comparable conditions at Kom Ombo Sugar Cane Research Station Farm, Aswan Governorate, Egypt. Milling tests with cane of both varieties and their crops were conducted periodically, on January, February and March throughout 2016/2017 milling season to investigate their milling qualities. At each test data of five samples from each crop of both varieties were used, exception on March, where the number of samples was 10 . Mother samples of $40 \mathrm{kgs}$ each were secured from erect and homogenous cane. Cane stalks were hand stripped and cleaned as described by Sayed (1972). The clean samples were sub-sampled to $30 \mathrm{kgs}$.

\section{Methods}

\section{Performance of cane varieties}

The methods adopted to determine the milling qualities for cane varieties was that described by Legendre and Henderson (1972) with the following modification:

1. Sample weight was $30 \mathrm{~kg}$ clean cane instead of $80 \mathrm{Ib}$. used by the authors.

2. Three roller hydraulic mills with 10 tons pressure extracted on the top roller were used instead of 3 roller mill with 32 tons pressure on the top roller used by the authors.

3. The samples were milled 6 times instead of 4 by the authors.

Data obtained from the complete milling test were:

1. Crusher juice weight, brix and apparent sucrose.

2. Secondary juice weight, brix and apparent sucrose (the secondary juice is the juice from last three millings and include parts of imbibition water).

3. Bagasse weight, apparent sucrose and fiber (\%) bagasse. From these data in the normal juice (juice as it occurs in cane) extraction and sucrose reduction factor (sucrose of normal juice divided by sucrose of crusher juice) were computed in this way:

1 - Normal juice brix $=$ crusher juice brix $\times 0.985$ (constant brix reduction factor). 
2- Brix product $=($ crusher juice weight $\times$ its brix $)$ + (secondary juice weight $\times$ its brix).

3- Normal juice weight $=$ brix product $\div$ normal juice brix.

4- Normal juice extraction= normal juice weight $\div$ weight of cane sample $\times 100$.

5 - Sucrose production $=($ crusher juice weight $\times$ its apparent sucrose $)+$ (secondary juice weight $\times$ its apparent sucrose).

6- Normal juice purity $=$ sucrose product $\div$ product brix.

7- Normal juice sucrose $=$ normal juice purity $\times$ normal juice brix.

8- Sucrose reduction factor $=$ normal juice sucrose $\div$ crusher juice sucrose.

Data obtained from milling test, namely, normal juice extraction pol and brix reduction factors were used to calculate yield per ton of cane according to the method described by Legendre and Henderson (1972) this equation is:

$$
\mathrm{S} 96^{\circ}=\mathrm{S} \times \text { pol factor- } \mathrm{b} \times \text { brix factor }
$$

Where:

$\mathrm{S} 96^{\circ}=$ is the $\mathrm{kg}$ of recoverable 96 pol sugar per ton cane.

$\mathrm{S}=$ is the number of 1 per cent increments of pol in the crusher juice.

$b=$ the number of 1 per cent increments of total solids in crusher juice.

Pol factors $=14.59 \times$ brix reduction factor $\times$ juice extraction.

\section{RESULTS AND DISCUSSION}

\section{Milling Qualities}

The various milling qualities indices for both variety, Giza 99/103 and Giza 99/160, in different crops were evaluated during January to March. The results obtained could be presented as follows.

\section{Normal juice extraction and bagasse (\%) cane}

Results in Table 1 compare normal juice extraction and bagasse per cent cane in both varieties during the study. Both varieties gave the highest normal juice extraction average of 79.2 by the onset of January, then normal juice extraction remained more or less constant from February to March, without any marked differences among the various crops, except the third ratoon crops of the variety Giza 99/160, which was characterized by slight reduction in normal juice extraction rate through the duration of study. The average normal juice extraction of both varieties was identical in January. During February and March, Giza 99/103 gave somewhat higher normal juice extraction compared to Giza $99 / 160$. It could be stated that normal juice extraction for Giza $99 / 160$ was $78.8 \%$ relative to the variety Giza 99/103, as an average for all crops through the duration of study.

Bagasse (\%) cane showed an opposite trend to normal juice extraction. The higher the normal juice extraction, the lower the bagasse (\%) cane. Bagasse $(\%)$ cane showed a slow gradual increase from January to March. However the variety Giza 99/160 having somewhat higher bagasse (\%) cane than Giza 99/130 (Bhatia et al., 2009; Saxena et al., 2010).

\section{Pol extraction and pol (\%) bagasse}

Pol extraction is the amount of sugar extracted in normal juice as percentage of pol contained in cane. Table 2 demonstrates pol extraction and pol (\%) final bagasse for the two varieties and their different crops at various test dates. In both varieties, pol extraction increased slightly from January to February, then kept more less constant until March. The variety Giza 99/160 showed somewhat higher pol extraction compared to the variety Giza 99/103. There were no marked differences among the different crops of the two varieties with regard to pol extraction. The increase in pol extraction showed reverse pattern to normal juice extraction, but it was in parallel to sugar cane maturity with attain optimum by the onset of March as reported by Muir and Eggleston (2009).

Changes in pol (\%) final bagasse showed a reversible trend to pol extraction. The higher the pol extraction, the lower the pol (\%) bagasse. Giza 99/130 variety and its different crops showed higher pol (\%) bagasse than Giza $99 / 160$, through the duration of study. The higher pol extraction reported for Giza 99/160 
Table 1. Average normal juice extraction and bagasse (\%) cane for the varieties Giza 99/103 and Giza 99/160 at different dates

\begin{tabular}{lccccc}
\hline Date of analysis & Crop & \multicolumn{2}{c}{ Normal juice extraction } & \multicolumn{2}{c}{ Bagasse (\%) cane } \\
\cline { 3 - 6 } & & Giza 99/103 & Giza 99/160 & Giza 99/103 & Giza 99/160 \\
\hline \multirow{3}{*}{ Onset of January } & Plant crop & 80.2 & 82.3 & 35.6 & 32.1 \\
& $\mathbf{1}^{\text {st }}$ ratton & 79.3 & 78.3 & 36.1 & 37.1 \\
& $\mathbf{2}^{\text {nd }}$ ratton & 78.2 & 78.5 & 37.8 & 35.9 \\
Average & $\mathbf{3}^{\text {rd }}$ ratton & 78.9 & 77.5 & 37.2 & 37.3 \\
& & 79.2 & 79.2 & 36.7 & 35.6 \\
Onset of February & & 78.0 & 79.2 & 38.1 & 35.1 \\
& $\mathbf{1}^{\text {st }}$ rant crop & 78.2 & 78.3 & 36.3 & 35.9 \\
Average & $\mathbf{2}^{\text {nd }}$ ratton & 79.5 & 77.0 & 36.1 & 38.3 \\
& $\mathbf{3}^{\text {rd }}$ ratton & 78.9 & 77.2 & 37.4 & 38.0 \\
Onset of March & & 78.7 & 77.9 & 37.0 & 36.8 \\
& $\mathbf{P l a n t}^{\text {st }}$ & 77.6 & 75.5 & 40.0 & 42.6 \\
Average & $\mathbf{2}^{\text {nd }}$ ratton & 79.7 & 78.6 & 35.2 & 37.3 \\
General average* & $\mathbf{3}^{\text {rd }}$ ratton & 78.6 & 76.6 & 37.5 & 39.6 \\
\hline
\end{tabular}

* The general average is sum mean of 80 determination.

Table 2. Average of pol extraction and pol (\%) cane bagasse for the varieties Giza 99/103 and Giza 99/160 at different dates.

\begin{tabular}{|c|c|c|c|c|c|}
\hline \multirow[t]{2}{*}{ Date of analysis } & \multirow[t]{2}{*}{ Crop } & \multicolumn{2}{|c|}{ Pol extraction } & \multicolumn{2}{|c|}{ Pol (\%) bagasse } \\
\hline & & Giza 99/103 & Giza 99/160 & Giza 99/103 & Giza 99/160 \\
\hline \multirow{4}{*}{ January } & Plant crop & 97.7 & 94.3 & 3.33 & 2.44 \\
\hline & $1^{\text {st }}$ ratton & 93.1 & 93.0 & 2.73 & 2.32 \\
\hline & $2^{\text {nd }}$ ratton & 91.3 & 93.5 & 3.27 & 2.42 \\
\hline & $3^{\text {rd }}$ ratton & 91.8 & 92.6 & 3.16 & 2.65 \\
\hline \multirow[t]{2}{*}{ Average } & & 92.2 & 93.4 & 3.12 & 2.46 \\
\hline & Plant crop & 92.3 & 94.2 & 3.57 & 2.52 \\
\hline \multirow{3}{*}{ February } & $1^{\text {st }}$ ratton & 93.8 & 94.2 & 2.61 & 2.15 \\
\hline & $2^{\text {nd }}$ ratton & 93.8 & 93.1 & 2.67 & 2.64 \\
\hline & $3^{\text {rd }}$ ratton & 92.9 & 93.2 & 3.07 & 2.71 \\
\hline \multirow[t]{2}{*}{ Average } & & 93.2 & 93.7 & 2.98 & 2.51 \\
\hline & Plant crop & 92.1 & 91.5 & 3.50 & 3.21 \\
\hline \multirow{3}{*}{ March } & $1^{\text {st }}$ ratton & 93.1 & 93.8 & 3.40 & 2.51 \\
\hline & $2^{\text {nd }}$ ratton & 92.7 & 92.9 & 3.36 & 2.93 \\
\hline & $3^{\text {rd }}$ ratton & 93.5 & 92.5 & 3.17 & 3.21 \\
\hline Average & & 92.9 & 92.7 & 3.36 & 2.97 \\
\hline General average* & & 92.8 & 93.2 & 3.15 & 2.64 \\
\hline
\end{tabular}

* The general average is sum mean of 80 determination. 
may be attributed to lower pol (\%) bagasse (2.64 compared to 3.15 for Giza 99/103) and hence lower sugar losses in bagasse (\%) cane. The higher pol (\%) bagasse reported with Giza 99/160 may be attributed to its initial higher pol per cent cane.

\section{Sucrose (pol) reduction factor}

This factor is used to convert crusher juice sucrose (pol) to normal juice sucrose (pol) as an adjustment in the calculations of theoretical sugar yield. An estimation of sucrose reduction factor for both varieties Giza 99/103 and Giza 99/160 and their different crops at different dates of analysis was done. Results obtained are presented in Table 3. When the milling season begon, i.e., in January, sucrose reduction factor of the standard variety Giza 99/103 showed insignificant variations among the different crops with an average of 0.977 for all the crops. Similar results were obtained during February (average value of 0.981) and on March (0.979) (Lingle et al., 2009).

The general average of 80 observations covering all crops and on different dates was 0.979 , the same factors showed the same trend in case of the new variety Giza 99/103, with slight variation among the different crops. The general average of 80 observations was 0.972 . Wang et al. (2007) reported that sucrose (pol) reduction factor was varietal character and it equaled to the average of 10 determinations covering the crops of a given variety.

\section{Varietal correction factor}

Giza 99/103 was adopted as the standard variety because it is the commercial variety grown in Egypt throughout the last decade. Values of normal juice extraction, sucrose (pol) of brix reduction factors (Tables 1 and 2) were used to calculate sucrose (pol) and brix factors and results were shown in Table 4. As shown in Tables 1 and 3, the cane variety Giza 99/103 had an average normal juice extraction of 78.9, and average sucrose reduction factor of 0.979 and brix reduction factor of 0.985 . These milling data led to an average sucrose (pol) and average brix factors of 11.26 and 3.24; respectively. They were adopted as standard for milling quality and together were assigned a value of 1.00 , which become the varietal correction factor of standard variety Giza 99/103. Giza $99 / 160$ cane variety is the new substitute to Giza $99 / 103$.

In assigning its varietal correction factors Results in Tables 1 and 3 were used to calculated sucrose (pol) and brix factors of 11.3 and 3.2; respectively obtained for Giza 99/160 variety and sucrose (pol) per cent and brix of crusher juice of this variety in the milling test, $\mathrm{kg}$. of sugar per ton of cane were calculated (designated "1" in Table 5). Again kg of sugar per ton of cane for the same variety were calculated using the same sucrose (pol) per cent and brix of crusher juice as in the first computation but substituting the sucrose and brix factors obtained for the standard variety Giza 99/103 (designated " 2 " in Table 5). Then the varietal correction for Giza 99/160 variety was obtained by dividing the first calculated $\mathrm{kg}$ sugar per ton of cane by the second one. As shown in Table 5, Giza 99/160 variety had an average varietal correction factor of 0.986 (rounded to 0.98). The varietal correction factor assigned to Giza $99 / 160$ variety is an index of its milling quality, expressed as sucrose and brix factors, in relation to that of the variety Giza 99/103 when grown under comparable conditions (Inman-Bamber et al., 2008).

Standard sucrose and brix factors for a range of varietal correction factors (0.92 to 1.08$)$ were calculated to facilitate the calculations of estimated recoverable sugar during varietal selection and evaluation programs. These values are presented in Table 6 .

\section{Cane and Juice Quality}

Results in Tables 7 and 8 show cane and normal juice quality parameters, pol (\%) cane, estimated recoverable sugar, pol (\%) normal juice and normal juice purity. At the beginning of milling season, early on January, both varieties showed relatively lower pol (\%) cane, lower estimated recoverable sugars, lower pol (\%) normal juice and lower normal juice purity. One month later, February, these indicated showed marked increase and remained constant thereafter.

Giza 99/103 was superior to Giza 99/160 variety in all the outlined characters except in normal juice purity which was found more or less equal to the Giza 99/160 variety. The recorded 
Table 3. Average sucrose reduction factor for Giza 99/103 and Giza 99/160 varieties on different dates

\begin{tabular}{lccc}
\hline Date of analysis & Crop & \multicolumn{2}{c}{ Sucrose reduction factor } \\
\cline { 3 - 4 } & & Giza 99/103 & Giza 99/160 \\
\hline \multirow{3}{*}{ Onset of January } & Plant crop & 0.977 & 0.974 \\
& $\mathbf{1}^{\text {st }}$ ratton & 0.976 & 0.975 \\
& $\mathbf{2}^{\text {nd }}$ ratton & 0.977 & 0.977 \\
Average & $\mathbf{3}^{\text {rd }}$ ratton & 0.978 & 0.978 \\
& & $\mathbf{0 . 9 7 7}$ & $\mathbf{0 . 9 7 6}$ \\
Onset of February & Plant crop & 0.981 & 0.981 \\
& $\mathbf{1}^{\text {st }}$ ratton & 0.982 & 0.978 \\
Average & $\mathbf{2}^{\text {nd }}$ ratton & 0.979 & 0.979 \\
& $\mathbf{3}^{\text {rd }}$ ratton & 0.981 & 0.980 \\
Onset of March & & $\mathbf{0 . 9 8 1}$ & $\mathbf{0 . 9 8 0}$ \\
& & 0.979 & 0.977 \\
Plant crop & 0.979 & 0.980 \\
Average & $\mathbf{1}^{\text {st }}$ ratton & 0.979 & 0.978 \\
General average* & $\mathbf{2}^{\text {nd }}$ ratton & 0.979 & 0.979 \\
\hline & $\mathbf{3}^{\text {rd }}$ ratton & $\mathbf{0 . 9 7 9}$ & $\mathbf{0 . 9 7 9}$ \\
& & $\mathbf{0 . 9 7 9}$ & $\mathbf{0 . 9 7 8}$ \\
\hline
\end{tabular}

Table 4. Average of sucrose factor, brix factors, estimated recoverable sugar and Varietal correction factor for the variety Giza 99/103

\begin{tabular}{lccccc}
\hline \multicolumn{1}{c}{ Date of analysis } & Crop & $\begin{array}{c}\text { Sucrose } \\
\text { factor }\end{array}$ & Brix factor & $\begin{array}{c}\text { Estimated } \\
\text { recoverable sugar }\end{array}$ & $\begin{array}{c}\text { Varietal correction } \\
\text { factor }\end{array}$ \\
\hline \multirow{3}{*}{ Onset of January } & Plant crop & 11.43 & 3.29 & 150.29 & 1.000 \\
& $\mathbf{1}^{\text {st }}$ ratton & 11.29 & 3.26 & 128.74 & 1.000 \\
& $\mathbf{2}^{\text {nd }}$ ratton & 11.15 & 3.21 & 128.08 & 1.000 \\
Average & $\mathbf{3}^{\text {rd }}$ ratton & 11.25 & 3.23 & 129.14 & 1.000 \\
& & 11.28 & 3.25 & 134.06 & 1.000 \\
Onset of February & $\mathbf{P l a n t}^{\text {st }}$ ratton & 11.16 & 3.20 & 161.62 & 1.000 \\
& $\mathbf{2}^{\text {nd }}$ ratton & 11.20 & 3.21 & 145.51 & 1.000 \\
Average & $\mathbf{3}^{\text {rd }}$ ratton & 11.29 & 3.26 & 140.58 & 1.000 \\
& & 11.25 & 3.23 & 148.23 & 1.000 \\
Onset of March & $\mathbf{P l a n t}^{\text {st }}$ rattop & 11.08 & 3.19 & 148.99 & 1.000 \\
& $\mathbf{2}^{\text {nd }}$ ratton & 11.38 & 3.27 & 152.44 & 1.000 \\
Average & $\mathbf{3}^{\text {rd }}$ ratton & 11.23 & 3.21 & 157.40 & 1.000 \\
General average* & & 11.26 & 3.26 & 157.68 & 1.000 \\
\hline
\end{tabular}

* The general average is sum mean of 80 determination. 
Zagazig J. Agric. Res., Vol. 46 No. (2) 2019

Table 5. Average of sucrose, brix factors, estimated recoverable sugar ${ }^{(1)}$, estimated recoverable sugar $^{(2)}$

\begin{tabular}{lcccccc}
\hline Date of analysis & Crop & $\begin{array}{c}\text { Sucrose } \\
\text { factor }\end{array}$ & $\begin{array}{c}\text { Brix } \\
\text { factor }\end{array}$ & $\begin{array}{c}\text { Estimated } \\
\text { recoverable } \\
\text { sugar }\end{array}$ & $\begin{array}{c}\text { Estimated } \\
\text { recoverable } \\
\text { sugar }^{(2)}\end{array}$ & $\begin{array}{c}\text { Varietal } \\
\text { correction } \\
\text { factor }\end{array}$ \\
\hline \multirow{2}{*}{ Onset of January } & Plant crop & 11.69 & 3.38 & 130.89 & 131.46 & 0.996 \\
& $\mathbf{1}^{\text {st }}$ ratton & 11.14 & 3.21 & 109.83 & 111.27 & 0.987 \\
& $\mathbf{2}^{\text {nd }}$ ratton & 11.19 & 3.22 & 121.52 & 121.14 & 1.003 \\
Average & $\mathbf{3}^{\text {rd }}$ ratton & 11.06 & 3.18 & 117.75 & 118.46 & 0.994 \\
& & 11.27 & 3.25 & 120.00 & 120.58 & 0.995 \\
Onset of February & $\mathbf{1}^{\text {ndant }}$ ratton & 11.33 & 3.25 & 146.15 & 144.00 & 1.015 \\
& $\mathbf{2}^{\text {rd }}$ ratton & 11.00 & 3.16 & 134.17 & 138.52 & 0.969 \\
Average & $\mathbf{3}^{\text {rd }}$ ratton & 11.04 & 3.17 & 139.09 & 142.26 & 0.978 \\
& & 11.14 & 3.20 & 135.82 & 137.29 & 0.989 \\
Onset of March & $\mathbf{P l}^{\text {st }}$ ratton & 11.24 & 3.23 & 139.47 & 141.20 & 0.988 \\
& $\mathbf{2}^{\text {nd }}$ ratton & 10.93 & 3.15 & 145.87 & 150.00 & 0.927 \\
& $\mathbf{3}^{\text {rd }}$ ratton & 11.03 & 3.17 & 156.08 & 160.44 & 0.973 \\
Average & & 10.99 & 3.16 & 147.03 & 150.66 & 0.976 \\
General average & & 11.13 & 3.20 & 134.28 & 136.18 & 0.986 \\
\hline
\end{tabular}

(1) Calculated using sucrose and brix factors obtained from varietal test.

(2) Calculated using sucrose and brix factors of the standard variety.

Table 6. Standard sucrose (pol) and brix factor corresponding to different values of varietal correction factor

\begin{tabular}{ccc}
\hline Varietal correction factor & Sucrose (pol) factor & Brix factor \\
\hline 0.92 & 10.36 & 2.98 \\
0.94 & 10.58 & 3.04 \\
0.96 & 10.81 & 3.11 \\
0.98 & 11.03 & 3.17 \\
1.00 & 11.26 & 3.24 \\
1.02 & 11.48 & 3.30 \\
1.04 & 11.71 & 3.37 \\
1.06 & 11.93 & 3.43 \\
1.08 & 12.16 & 3.50 \\
\hline
\end{tabular}


Table 7. Average of cane and juice quality parameters of Giza 99/103 cane variety

\begin{tabular}{|c|c|c|c|c|c|c|}
\hline Date of analysis & Crop & $\begin{array}{c}\text { Normal } \\
\text { juice purity }\end{array}$ & $\begin{array}{c}\text { Pol (\%) } \\
\text { normal juice }\end{array}$ & $\begin{array}{c}\text { Estimated recoverable } \mathrm{F} \\
\text { sugar }(\%) \text { cane }\end{array}$ & $\begin{array}{l}\text { Pol }(\%) \\
\text { cane }\end{array}$ & $\begin{array}{l}\text { Age of cane } \\
\text { (month) }\end{array}$ \\
\hline \multirow{4}{*}{ January } & Plant crop & 89.0 & 18.92 & 15.30 & 16.36 & 11 \\
\hline & $1^{\text {st }}$ ratton & 86.7 & 16.61 & 12.87 & 14.16 & 8 \\
\hline & $2^{\text {nd }}$ ratton & 86.4 & 16.75 & 12.81 & 14.33 & 9 \\
\hline & $3^{\text {rd }}$ ratton & 85.3 & 16.75 & 12.91 & 14.39 & 8 \\
\hline \multirow[t]{2}{*}{ Average } & & 86.9 & 17.22 & 13.47 & 14.81 & \\
\hline & Plant crop & 80.9 & 20.72 & 16.16 & 17.52 & 12 \\
\hline \multirow{3}{*}{ February } & $1^{\text {st }}$ ratton & 89.4 & 18.41 & 14.55 & 15.34 & 9 \\
\hline & $2^{\text {nd }}$ ratton & 87.6 & 18.00 & 14.05 & 15.27 & 10 \\
\hline & $3^{\text {rd }}$ ratton & 89.1 & 18.80 & 14.82 & 15.98 & 9 \\
\hline \multirow[t]{2}{*}{ Average } & & 89.3 & 18.98 & 14.90 & 16.03 & \\
\hline & Plant crop & 90.6 & 20.96 & 16.24 & 17.66 & 13 \\
\hline \multirow{3}{*}{ March } & $1^{\text {st }}$ ratton & 89.9 & 20.12 & 15.94 & 17.23 & 10 \\
\hline & $2^{\text {nd }}$ ratton & 85.4 & 20.08 & 15.73 & 17.03 & 11 \\
\hline & $3^{\text {rd }}$ ratton & 89.5 & 19.75 & 15.57 & 16.76 & 10 \\
\hline Average & & 89.9 & 20.23 & 15.87 & 17.17 & \\
\hline General average & & 88.65 & 18.82 & 14.75 & 16.00 & \\
\hline
\end{tabular}

Table 8. Average of cane and juice quality parameters of Giza 99/160 cane variety

\begin{tabular}{|c|c|c|c|c|c|c|}
\hline Date of analysis & Crop & $\begin{array}{c}\text { Normal } \\
\text { juice purity }\end{array}$ & $\begin{array}{c}\text { Pol (\%) } \\
\text { normal juice }\end{array}$ & $\begin{array}{c}\text { Estimated recoverable } \\
\text { sugar }(\%) \text { cane }\end{array}$ & $\begin{array}{l}\text { Pol }(\%) \\
\text { cane }\end{array}$ & $\begin{array}{l}\text { Age of cane } \\
\text { (month) }\end{array}$ \\
\hline \multirow{4}{*}{ January } & Plant crop & 87.8 & 16.02 & 13.09 & 13.97 & 11 \\
\hline & $1^{\text {st }}$ ratton & 84.2 & 14.55 & 10.98 & 12.25 & 8 \\
\hline & $2^{\text {nd }}$ ratton & 87.1 & 15.80 & 12.15 & 13.27 & 9 \\
\hline & $3^{\text {rd }}$ ratton & 85.7 & 15.62 & 11.78 & 13.66 & 8 \\
\hline \multirow[t]{2}{*}{ Average } & & 86.2 & 15.50 & 12.00 & 13.14 & \\
\hline & Plant crop & 89.9 & 18.55 & 14.62 & 15.58 & 12 \\
\hline \multirow{3}{*}{ February } & $1^{\text {st }}$ ratton & 87.8 & 16.07 & 12.39 & 13.35 & 9 \\
\hline & $2^{\text {nd }}$ ratton & 88.5 & 17.64 & 13.42 & 14.59 & 10 \\
\hline & $3^{\text {rd }}$ ratton & 88.6 & 18.22 & 13.91 & 15.10 & 9 \\
\hline \multirow[t]{2}{*}{ Average } & & 88.7 & 17.62 & 13.59 & 14.66 & \\
\hline & Plant crop & 89.7 & 19.53 & 14.67 & 16.11 & 13 \\
\hline \multirow{3}{*}{ March } & $1^{\text {st }}$ ratton & 88.7 & 17.95 & 13.65 & 15.64 & 16 \\
\hline & $2^{\text {nd }}$ ratton & 89.7 & 19.96 & 14.59 & 16.45 & 11 \\
\hline & $3^{\text {rd }}$ ratton & 91.0 & 20.12 & 15.61 & 16.77 & 16 \\
\hline Average & & 89.8 & 19.34 & 14.63 & 16.69 & \\
\hline General average & & 88.2 & 17.50 & 13.41 & 14.63 & \\
\hline
\end{tabular}


general average for all crops and test dates for pol (\%) cane, estimated recoverable sugars, pol (\%) normal juice and normal juice purity for the variety Giza 99/103 were 16.00, 14.75, 18.82 and 88.65 , respectively, compared to 14.63 , $13.41,17.50$ and 88.2 for Giza 99/160 variety. These results are conformed by those of Kennedy (2005) who stated that the maturity phase, beginning on March was marked by progress arise in sucrose storage. Its also added that Giza 99/103 was superior to Giza 99/160 with respect to their sucrose content, and that Giza 99/103 was an early maturing variety followed by Giza 99/160.

Within the different crops of each variety, as shown in Tables 6 and 7, the plant crops were higher in all the quality parameters outlined before. Such result disagree with the findings of (Gravois and Bischoff, 2008; Tew et al., 2009). However, this could be attributed to variations in the age of each crop at test times. At all dates of analysis, plant crop was 1 to 2 months older than ratoon crops, which many explain the high quality of plant crop over ratoon recorded in this study.

\section{Conclusion}

Giza 99/130 variety and its different crops showed higher pol (\%) bagasse than Giza $99 / 160$, through the duration of study. Giza 99/103 was superior to Giza 99/160 variety in all the outlined characters except in normal juice purity which was found more or less equal to the Giza 99/160 variety. Giza 99/103 was superior to Giza $99 / 160$ with respect to their sucrose content, and that Giza 99/103 was an early maturing variety followed by Giza 99/160.

\section{REFERENCES}

Anon (1974). Mumias sugar company limited. Anew project in Kenya. Sugar Y. Azucar, 69 (6): $41-156$.

Bhatia, S.J., S.K. Uppal, K.S. Thind and S.K. Batta (2009). Post harvest quality deterioration in sugarcane under different environmental conditions. Sugar Technol., 11 (2): 154160.

Cargill, T.M. and A.H. Winterbach (1996). An imovative sugar mill. Construction and first two years of operation at Komati. Int. Sugar J., 98 (1169): 225 - 229.

Gonzaies, J.E. (2001). Method for producing sugar cane juice. United State Patent, US., 6: (245): 153.

Gravois, K.A. and K.P. Bischoff (2008). New sugarcane varieties to the rescue. Louisiana Agric., 51 (2): 14-16.

Inman-Bamber, N.G., G.D. Bonnett, M.F. Spillman, M.L. Hewitt and J. Jackson (2008). Increasing sucrose accumulation in sugarcane by manipulating leaf extension and photosynthesis with irrigation. Aust. J. Agric. Res., 59 : $13-26$.

Kennedy, A.J. (2005). Breeding improved cultivars for the Caribbean by utilization of total biomass production. Proc. Int. Soc. Sugar Cane Technol., 25: 491-499.

Laksameethanasana, P., N. Somla, S. Janprem and N. Phochuen (2012). Clarification of sugarcane juice for syrup production. Procedia Eng., 32: 141 - 147.

Legendre, B.L. and M.T. Henderson (1972). The history and development of sugar yield calculation. Proceeding of 1972 meeting of Ame. Soc. Sugar Cane Technol.

Lingle, S.E., R.P. Viator, R.M. Johnson, T.L. Tew and D.L. Boykin (2009). Recurrent selection for sucrose content has altered growth and sugar accumulation in sugarcane. Field Crops Res., 113 (3): 306-311.

Muir, B. and G. Eggleston (2009). Factory trials to determine how sugarcane trash impacts downstream processing including affinated sugar production. Proc. Sugar Industry Technol. Meeting Vol. LXVIII No. 960: 2448.

Prieto, T. (1997). The Okeelanta sugar factory. A report on the expansion of Florida's second oldest mill sugar Y. Azucar, 72: 6: 58 - 60 and 131-132.

Saxena, P., R.P. Srivastava and M.L. Sharma (2010). Impact of cut to crush delay and biochemical changes in sugarcane. Aust. J. Crop Sci., 4 (9): 692699. 
Sayed, G.E. (1972). Changes in the Sugar Components of Cane During Growth and Processing. Ph.D. Thesis, Fac. Agric., Univ. Assiut.

Shweil, S. F. (1999). Diversification of sugar industry in Egypt. Egypt. Sugar J., 1:1 - 11.

Tew, T.L., E.O. Dufrene, D.D. Garrison, W.H. White, M.P. Grisham, Y.B. Pan, E.P.
Richard Jr., B.L. Legendre and J.D. Miller (2009). Registration of ' $\mathrm{HoCP}$ 00-950' Sugarcane. J. Plant Regetrations, 3 (1): $42-$ 50 .

Wang, C., Z. Chen and J.H. Wang (2007). "Analysis of cane juice quality indexes of main sugarcane varieties in Zhanjiang area," Sugar Crops of China, 4.

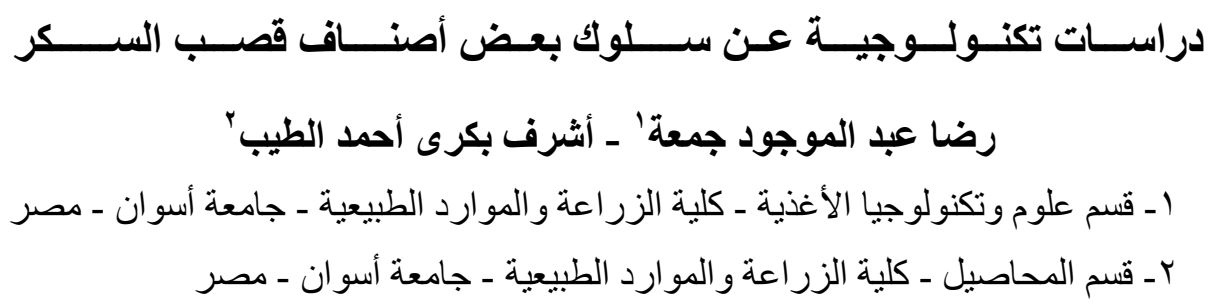

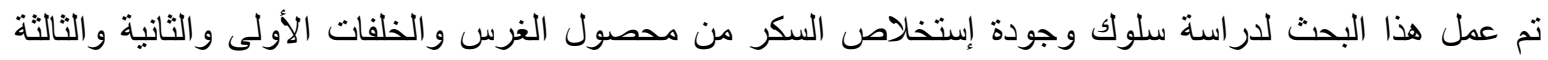

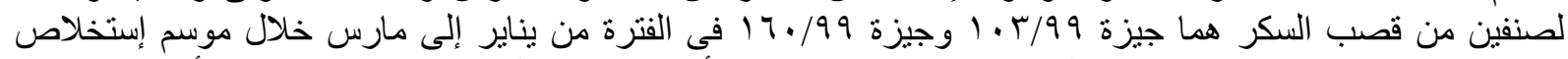

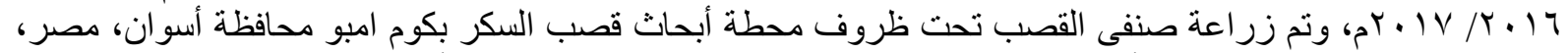

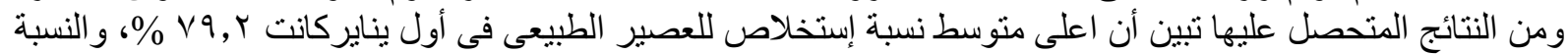

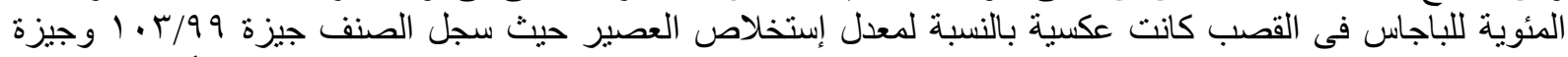

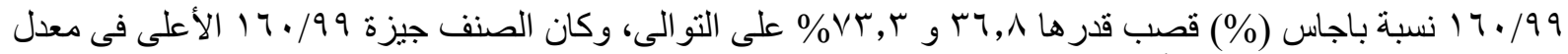

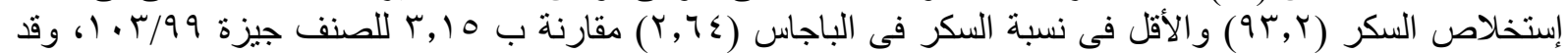

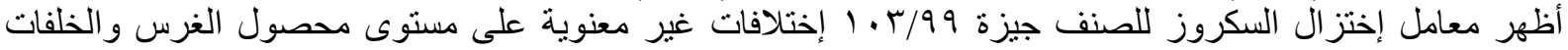

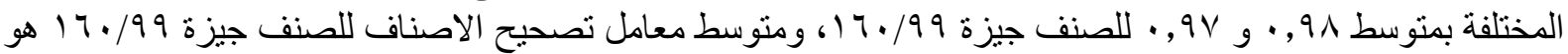

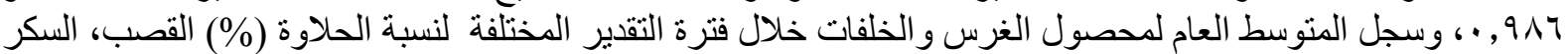

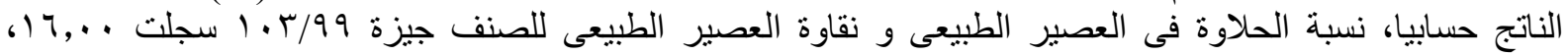

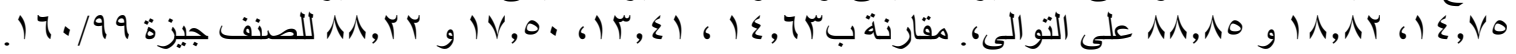

أستاذ منفر غ بقسم علوم الأغذية ـ كلبة الزر اعة ـ جامعة أسبوط.

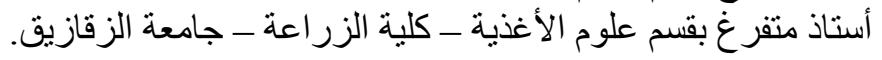

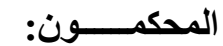

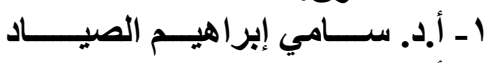

ץ أ.د. محمد رجب محمد عبدالمجيد 